\title{
Korelasi Modified Nutric Score dengan Mortalitas 28 Hari Pasien Sepsis di Unit Perawatan Intensif RSUP Dr. Mohammad Hoesin Palembang
}

\author{
Rieke Cahyo Budi Utami, ${ }^{1}$ Zulkifli, ${ }^{2}$ Rizal Zainal, ${ }^{3}$ Irsan Saleh ${ }^{4}$ \\ ${ }^{1}$ PPDS Anestesiologi dan Terapi Intensif Fakultas Kedokteran Universitas Sriwijaya/RSUP Dr. \\ Mohammad Hoesin Palembang, 2,3Bagian Anestesi Fakultas Kedokteran Universitas Sriwijaya/ \\ RSUP Dr. Mohammad Hoesin Palembang, ${ }^{4}$ Bagian Biomedik Fakultas Kedokteran \\ Universitas Sriwijaya
}

\begin{abstract}
Abstrak
Malnutrisi merupakan masalah penting pada pasien sepsis karena memperburuk outcome akibat penyembuhan luka terganggu, menurunkan fungsi imun, risiko infeksi tinggi, kelemahan otot sehingga weaning ventilator mekanik lebih sulit, meningkatkan lama tinggal dan biaya tinggi di unit perawatan intensif serta peningkatan mortalitas. Skrining risiko nutrisi saat pasien masuk unit perawatan intensif dengan modified NUTRIC score dapat mengidentifikasi kelompok risiko nutrisi tinggi atau risiko rendah. Penelitian kohort retrospektif untuk mengetahui korelasi antara modified NUTRIC score dengan mortalitas pada pasien sepsis yang dirawat dari Januari-Desember 2018 di RSUP Dr. Mohammad Hoesin Palembang. Jumlah sampel 100 orang, dibagi 2 kelompok berdasarkan mortalitas, kemudian dilakukan pengukuran modified NUTRIC score yang terdiri dari usia, skor APACHE II, skor SOFA, lama rawat sebelum masuk perawatan intensif, dan jumlah komorbid. Modified NUTRIC score memiliki nilai 0-9. Hasil analisis ROC curve modified NUTRIC score dengan mortalitas didapatkan sensitiftas sebesar $96 \%$, spesifisitas $71 \%$, nilai area under the curve (AUC) 0,916 dengan nilai cut off $>4$. Terdapat korelasi antara modified NUTRIC score dengan mortalitas dalam 28 hari pasien sepsis dengan koefisien korelasi $(\mathrm{r})=0,716$ dan nilai $p=0,0001$.
\end{abstract}

Kata kunci: Modified NUTRIC score, mortalitas, sepsis

\section{Correlation of Modified Nutric Score with 28-Day Mortality in Sepsis Patients at Intensive Care Unit of Dr. Mohammad Hoesin General Hospital Palembang}

\begin{abstract}
Malnutrition is an essential problem to septic patients because it worsens the outcome due to impaired wound healing, decreases immune function, high risk of infection, and muscle weakness so that mechanical ventilator weaning is more complicated. Also, it increases the patient length of stay and costs in the intensive care unit and increases mortality. Nutrition risk screening on patients' admission to the intensive care unit with modified NUTRIC score can identify groups of high nutritional risk or low risk. The retrospective cohort study aimed to determine the correlation between modified NUTRIC score and mortality in sepsis patients treated from January-December 2018 at dr. Mohammad Hoesin General Hospital Palembang. The total sample of 100 people was divided into 2 groups based on mortality then measured with modified NUTRIC score consisting of age, APACHE II score, SOFA score, length of stay before admission to the intensive care, and the number of comorbid based on data from medical records. Modified NUTRIC score has a value of $0-9$. The ROC curve modified NUTRIC score with mortality was $96 \%$ sensitivity, $71 \%$ specificity, area under curve (AUC) value 0.916 with a cut-off value $>4$. There is a correlation between the modified NUTRIC score and mortality in 28 days in sepsis patients in the Intensive Care Unit of Dr. Mohammad Hoesin General Hospital Palembang with a correlation coefficient $(r)=0,716$ and $p$ value $<0,05$.
\end{abstract}

Key words: Modified NUTRIC score, mortality, sepsis

Korespondensi: dr. Rieke Cahyo Budi Utami, PPDS Anestesiologi dan Terapi Intensif FK Universitas Sriwijaya, Jl. Dr. Mohammad Ali, Sekip Jaya, Kec. Kemuning, Palembang Sumatera Selatan, Tlpn 0711-367765, Email riekecahyobudi@ yahoo.com 


\section{Pendahuluan}

Sepsis dan syok sepsis masih menjadi masalah kesehatan utama di dunia, yang mengakibatkan satu dari empat orang meninggal. ${ }^{1}$ Angka kejadian sepsis tahun 2017 dari General Intensive Care Unit (GICU) RSUP dr. Mohammad Hoesin Palembang sebesar $30,1 \%$ dengan angka kematian 28 hari mencapai 46,8\%. ${ }^{2}$ Sepsis dan kondisi kritis lain dapat menyebabkan malnutrisi akibat stres katabolisme dan input nutrisi tidak adekuat. Pada fase akut sepsis terjadi pelepasan hormon katabolisme (glukagon, kortisol, dan katekolamin) yang menyebabkan katabolisme pada otot serta pemecahan glikogen, dan jaringan lemak untuk menghasilkan energi bagi organ vital seperti otak dan jantung. Pada saat yang sama, terjadi pelepasan sitokin proinflamasi seperti interleukin (IL)-1, IL6 , tumor necrosis factor (TNF)- $\alpha$ yang akan memperberat proses katabolisme., ${ }^{3,4}$

Kondisi malnutrisi tersebut menjadi masalah penting pada pasien kritis termasuk pasien sepsis karena memperburuk outcome yang menyebabkan penyembuhan luka terganggu, menurunnya fungsi imun, meningkatkan risiko infeksi, kelemahan otot, sehingga weaning ventilator mekanik lebih sulit, yang akan meningkatkan lama tinggal dan biaya tinggi di unit perawatan intensif, serta peningkatan mortalitas. ${ }^{5,6,7}$ Skrining nutrisi saat awal pasien masuk unit perawatan intensif dapat mengidentifikasi risiko nutrisi tinggi atau risiko rendah. Beberapa penelitian sebelumnya menunjukkan korelasi antara skrining nutrisi dengan mortalitas pada pasien kritis dan atau sepsis. ${ }^{5,6,8-13}$

Skrining nutrisi pada pasien-pasien di Unit Perawatan Intensif RSUP dr. Mohammad Hoesin Palembang baik pada pasien sepsis atau pasien kritis lainnya selama ini menggunakan subjective global assesment dengan parameter perubahan berat badan, nafsu makan dan perubahan nafsu makan yang tidak dapat diaplikasikan dengan baik pada pasien kritis terutama pada pasien sepsis. Perlu dilakukan skrining risiko nutrisi yang menggunakan parameter beratnya penyakitseperti modified
NUTRIC score sebagai panduan terapi nutrisi yang adekuat untuk dapat memperbaiki prognosis pasien. ${ }^{1,3}$ Tujuan penelitian ini adalah mengetahui korelasi antara modified NUTRIC score dengan mortalitas dalam 28 hari pada pasien sepsis di Unit Perawatan Intensif RSUP dr. Mohammad Hoesin Palembang. Kriteria inklusi adalah pasien yang memiliki data rekam medis lengkap, pasien yang masuk dirawat di unit rawat intensif RSUP dr. Mohammad Hoesin Palembang, pasien dengan diagnosis sepsis dan usia $\geq 18$ tahun.

Kriteria eksklusi adalah pasien rujukan atau pindahan dari ruang rawat intensif rumah sakit lain, di rawat di unit rawat intensif RSUP dr. Mohammad Hoesin Palembang kurang dari 24 jam, pasien re-admisi ke unit perawatan intensif dalam satu periode perawatan yang sama. Jumlah sampel ditentukan dengan total sampling dan didapatkan 100 pasien sepsis dalam rentang waktu 1 Januari-31 Desember 2018 yang memenuhi kriteria inklusi dan tidak termasuk kriteria eklusi. Kemudian sampel tersebut dibagi menjadi 2 kelompok berdasarkan mortalitas yaitu kelompok meninggal dan kelompok tidak meninggal. Tiap sampel dilakukan pengukuran karakteristik dasar dan nilai modified NUTRIC score. Karakteristik dasar terdiri dari usia, jenis kelamin, lama perawatan di ruang intensif, dan diagnosis. Sedangkan modified NUTRIC score terdiri atas parameter usia, skor APACHE II, skor SOFA, lama rawat sebelum masuk perawatan intensif, dan jumlah komorbid berdasarkan data dari rekam medis. Tiaptiap parameter dibagi lagi menjadi beberapa kategori dan tiap kategori memiliki nilai, yang setelah dijumlahkan didapatkan nilai modified NUTRIC score. Modified NUTRIC score memiliki nilai minimal 0 , dan nilai maksimal 9. Dilakukan analisis data untuk mencari korelasi antara modified NUTRIC score dengan mortalitas dalam 28 hari. Data dianalisis menggunakan uji-t tidak berpasangan, Uji Mann-Whitney, uji chi-square, uji kurva ROC. Nilai yang bermakna secara statistik adalah nilai $\mathrm{p}<0,05$. Analisis data menggunakan statistical product and service solution (SPSS) versi 22.0. 


\section{Hasil}

Berdasar atas karekteristik usia didapatkan bahwa rerata pasien yang meninggal lebih tinggi dibanding dengan pasien yang hidup namun perbedaan tersebut tidak bermakna ( $p>0,05)$. Didapatkan $64 \%$ pasien laki-laki dan $36 \%$ pasien perempuan, dan tidak ada perbedaan bermakna antara pasien meninggal dan pasien tidak meninggal ( $p>0,05)$.

Angka mortalitas pada pasien dengan lama perawatan di ruang intensif $>9$ hari lebih tinggi disbanding dengan pasien dengan lama perawatan di ruang intensif $>9$ hari $(63,8 \%$ vs $35,5 \%$ ) dengan perbedaan yang signifikan $(p<0,05)$. Sedangkan angka mortalitas pada infeksi saluran nafas lebih besar dibanding dengan infeksi saluran cerna dan infeksi lainnya $(66,7 \%$ vs $53,7 \%$ vs $29,4 \%)$ dengan perbedaan yang signifikan ( $\mathrm{p}<0,05$; Tabel 1 ).

Nilai rerata modified NUTRIC score dan parameternya serta hubungannya dengan mortalitas dapat dilihat pada Tabel 2.
Hasil analisis ROC Curve Modified NUTRIC score terhadap mortalitas (Tabel 3) didapatkan nilai sensitiftas sebesar $96 \%$, nilai spesifisitas sebesar $71 \%$, nilai cut-off point didapatkan $>4$ dan nilai area under curve (AUC) sebesar 0,916 .

Analisis korelasi modified NUTRIC score berdasarkan cut off point terhadap mortalitas pasien sepsis didapatkan korelasi bermakna antara modified NUTRIC score berdasarkan cut off point terhadap mortalitas pasien sepsis $(p<0,05)$ dengan nilai r 0,176 (korelasi kuat).

\section{Pembahasan}

Hubungan karakteristik dasar dengan mortalitas pasien sepsis didapatkan bahwa usia rerata antara yang tidak meninggal dan kelompok yang meninggal tidak ada perbedaan. Teori menyatakan bahwa terdapat hubungan antara usia dengan kematian pada pasien sepsis. Dengan kejadian sepsis lebih sering pada usia ekstrim. Kejadian sepsis paling

Tabel 1 Karakteristik Dasar Subjek Penelitian dengan Mortalitas Pasien

\begin{tabular}{|c|c|c|c|c|}
\hline \multirow[b]{2}{*}{ Karakteristik } & \multicolumn{4}{|c|}{ Mortalitas } \\
\hline & $\begin{array}{l}\text { Jumlah } \\
\text { n (\%) }\end{array}$ & Meninggal & Tidak Meninggal & Nilai p \\
\hline Usia & & & & $0,961^{* *}$ \\
\hline$<50$ tahun & 39 & $22(56,4 \%)$ & $17(43,6 \%)$ & \\
\hline 50-75 tahun & 57 & $31(54,4 \%)$ & $26(45,6 \%)$ & \\
\hline$>75$ tahun & 4 & $2(50 \%)$ & $2(50, \%)$ & \\
\hline Rerata & $52 \pm 15,00$ & $53,98 \pm 13,93$ & $49,96 \pm 16,10$ & $0,281^{*}$ \\
\hline Median & & 53,98 & 56 & \\
\hline Min.-Maks. & $(18-82)$ & $(26-82)$ & $(18-81)$ & \\
\hline Jenis kelamin & & & & $0,212^{* *}$ \\
\hline Laki-laki & 64 & $32(58,2 \%)$ & $32(71,1 \%)$ & \\
\hline Perempuan & 36 & $23(41,8 \%)$ & $13(28,9 \%)$ & \\
\hline Lama perawatan di ruang intensif & & & & $0,016^{* *}$ \\
\hline$\leq 9$ hari & 69 & $44(63,8 \%)$ & $25(36,2 \%)$ & \\
\hline$>9$ hari & 31 & $11(35,5 \%)$ & $20(64,5 \%)$ & \\
\hline Rerata & $9,03 \pm 8,57$ & $7,09 \pm 6,21$ & $11,40 \pm 10,37$ & $0,018 *$ \\
\hline Median & & 5 & 8 & \\
\hline Min.-Maks. & $1-46$ & $1-33$ & $1-46$ & \\
\hline Diagnosis & & & & $0,033^{* *}$ \\
\hline Infeksi saluran pernafasan & 42 & $28(66,7 \%)$ & $14(33,3 \%)$ & \\
\hline Infeksi saluran pencernaan & 41 & $22(53,7 \%)$ & $19(46,3 \%)$ & \\
\hline Lain-lain & 17 & $5(29,4 \%)$ & $12(70,6 \%)$ & \\
\hline
\end{tabular}

Keterangan: * ujiMann-Whitney** uji chi square 
Tabel 2 Perbedaan Modified NUTRIC Score dengan Mortalitas Pasien Sepsis

\begin{tabular}{|c|c|c|c|c|}
\hline \multirow[b]{2}{*}{ Variabel } & \multirow[b]{2}{*}{ Total } & \multicolumn{2}{|c|}{ Mortalitas } & \multirow[b]{2}{*}{ Nilai p } \\
\hline & & $\begin{array}{l}\text { Meninggal } \\
\text { n (\%) }\end{array}$ & $\begin{array}{c}\text { Tidak Meninggal } \\
\text { n (\%) }\end{array}$ & \\
\hline Modified NUTRIC score & & & & \\
\hline Rerata $\pm S D$ & $5,14 \pm 1,72$ & $6,25 \pm 1,05$ & $3,78 \pm 1,38$ & 0,000 \\
\hline Median (min-maks.) & $5(1-9)$ & $6(4-9)$ & $4(1-7)$ & \\
\hline Usia & & & & $0,961^{* *}$ \\
\hline$<50$ tahun & & $22(56,4)$ & $17(43,6)$ & \\
\hline 50-75 tahun & & $31(54,4)$ & $26(45,6)$ & \\
\hline$>75$ tahun & & $2(50)$ & $2(50)$, & \\
\hline Rerata $\pm S D$ & $52,17 \pm 15,00$ & $53,98 \pm 13,93$ & $49,96 \pm 16,10$ & $0,281^{* * *}$ \\
\hline Median (Min.-Maks.) & $56(18-82)$ & $53,98(26-82)$ & $56(18-81)$ & \\
\hline Skor APACHE II & & & & $0,000 * *$ \\
\hline$<15$ & & $1(8,3)$ & $11(91,7)$ & \\
\hline $15-19$ & & $3(20)$ & $12(80)$ & \\
\hline $20-28$ & & $29(60,4)$ & $19(39,6)$ & \\
\hline$\geq 29$ & & $22(88)$ & $3(12)$ & \\
\hline Rerata $\pm S D$ & $23,51 \pm 6,62$ & $26,83 \pm 5,81$ & $19,44 \pm 5,14$ & $0,000^{*}$ \\
\hline Median (Min-Maks.) & $23(11-41)$ & & & \\
\hline Skor SOFA & & & & $0,000 * *$ \\
\hline$<6$ & & $0(0)$ & $21(100)$ & \\
\hline $6-9$ & & $29(55,8)$ & $23(44,2)$ & \\
\hline$\geq 10$ & & $26(96,3)$ & $1(3,7)$ & $0,000 * * *$ \\
\hline Rerata \pm SD & $7,90 \pm 3,02$ & $9,69 \pm 2,37$ & $5,71 \pm 2,17$ & \\
\hline Median (min-maks.) & $8(2-14)$ & $9(6-14)$ & $6(2-12)$ & \\
\hline Jumlah komorbid & & & & $0,000 * *$ \\
\hline $0-1$ & - & $4(16)$ & $21(84 \%)$ & \\
\hline$\geq 1$ & & $51(68)$ & $24(32 \%)$ & \\
\hline Lama Rawat sebelum intensif & & & & $0,626^{* *}$ \\
\hline $0-<1$ & & $9(47,4)$ & $10(52,6)$ & \\
\hline$\geq 1$ & - & $46(56,8)$ & $35(43,2)$ & \\
\hline
\end{tabular}

Keterangan: * Uji-t tidak berpasangan, ** Uji Chi-Square, ${ }^{* * *}$ Uji Mann-Whitney

rendah pada anak-anak dan dewasa muda kemudian meningkat pada rentang usia 50-85 tahun dan diatasnya. Di negara berkembang, kematian terkait sepsis paling banyak (71\%) pada pasien umur $\geq 65$ tahun. Kejadian dan mortalitas sepsis yang lebih tinggi pada usia tua disebabkan karena 2 faktor, yaitu usia tua lebih sering disertai penyakit kronis (kanker, penyakit ginjal kronis, dll.) dan penurunan fungsi imun terkait usia tua yang dikenal dengan istilah immunosenescence. ${ }^{14}$

Penelitian yang dilakukan oleh Jeong $\mathrm{dkk}^{8}$

Tabel 3 ROC Curve Modified NUTRIC Score terhadap Mortalitas

\begin{tabular}{lcc}
\hline \multicolumn{1}{c}{ Modified NUTRIC Score } & Nilai & $\mathbf{9 5 \%}$ IK \\
\hline Sensitifitas & $96 \%$ & \\
Spesifisitas & $71 \%$ & $(86-99)$ \\
AUC & 0,916 & $(55-83)$ \\
Youden indeks & 0,6747 & $(0,843-0,962)$ \\
Associated criterion & $>4$ & \\
\hline
\end{tabular}




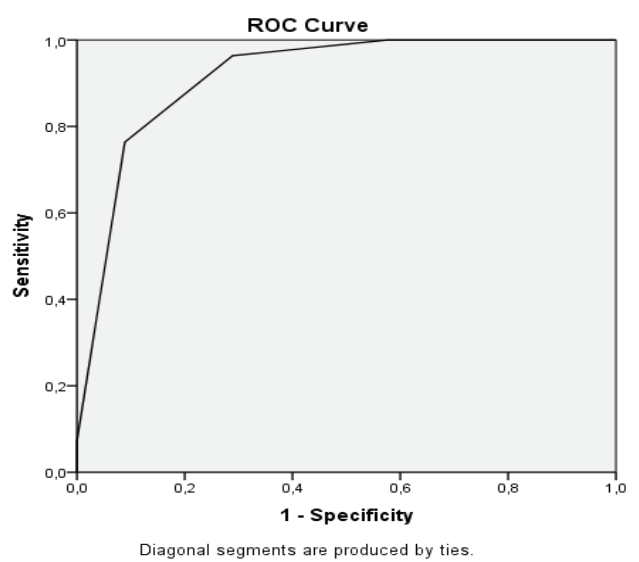

Gambar ROC CurveModified NUTRIC Score terhadap Mortalitas

didapatkan rerata usia pasien sepsis pada kelompok yang low score adalah 62 tahun dan pada kelompok yang high score adalah 68 tahun, serta dari analisis statistik perbedaan tersebut bermakna.Penelitian Kalaiselvan dkk didapatkan ada perbedaan yang bermakna antara usia pada kelompok yang high score dan low score, yaitu rerata usia pada kelompok low score $49,9 \pm 17$ tahun dan pada kelompok high score $66 \pm 13,2$ tahun. Berdasarkan Mukhopadhyay dkk ${ }^{10}$ pada pasien sakit kritis juga mendapatkan bahwa terdapat perbedaan bermakna antara usia dengan mortalitas didapatkan rerata usia pada kelompok yang tidak meninggal 59,1 $\pm 16,4$ dan rerata usia pada kelompok yang meninggal $63,6 \pm 15,5$.

Hubungan jenis kelamin dengan mortalitas pada pasien sepsis didapatkan hasil yang tidak berbeda signifikan. Kejadian dan mortalitas pasien sepsis berdasar atas teori lebih tinggi pada laki-laki dibanding dengan perempuan. ${ }^{14,15}$ Hal ini dipengaruhi oleh hormon terhadap fungsi imun, yaitu hormon androgen memiliki efek supresif terhadap respons imun dan sebaliknya hormon pada perempuan memiliki efek protektif. ${ }^{13} \mathrm{Hal}$ ini hampir serupa dengan hasil penelitian yang menyatakan bahwa tidak didapatkan perbedaan bermakna untuk jenis kelamin pada kelompok low-score dan high-score Modified NUTRIC Score. ${ }^{8}$

Hubungan diagnosis dengan kematian pada pasien sepsis didapatkan hubungan yang bemakna dengan diagnosis terbanyak infeksi saluran pernapasan. Hal ini sesuai dengan penelitian sebelumnya bahwa sumber infeksi yang tersering pada sepsis adalah infeksi sistem respirasi (pneumonia), sistem gastrointestinal, sistem urogenital, infeksi aliran darah, infeksi kulit dan jaringan lunak, dan infeksi sistem saraf pusat. ${ }^{14}$ Namun dari penelitian Jeong $\mathrm{dkk}^{8}$ didapatkan tidak ada perbedaan bermakna antara diagnosis pada kelompok low-score dan high-score modified NUTRIC score.

Berdasar atas distribusi lama perawatan didapat rerata lama perawatan pada kelompok yang meninggal 7,09 $\pm 6,21$ hari dan kelompok yang tidak meninggal $11,40 \pm 10,37$ hari. Dengan perbedaan bermakna antara kelompok pasien yang meninggal dan tidak meninggal. Hal yang hampir sama didapatkan

Tabel 4 Korelasi Modified NUTRIC Score dengan Mortalitas pada Pasien Sepsis

\begin{tabular}{ccrc}
\hline Variabel & Korelasi & r & Nilai p \\
\hline Modified NUTRIC score dengan Mortalitas & Eta & 0,716 & $<0,0001^{* *}$ \\
\hline $\begin{array}{l}\text { Keterangan: nilai kemaknaan p<0,05, tanda ** menunjukkan signifikan atau bermakna secara statistika. } \mathrm{r} \text { :koefisien } \\
\text { korelasi Eta }\end{array}$
\end{tabular}


pada penelitian sebelumnya bahwa terdapat perbedaan bermakna lama perawatan di unit perawatan intensif antara kelompok high score yaitu 8 hari dan kelompok low score yaitu 5 hari. $^{8}$

Rerata nilai modified NUTRIC score pada kelompok yang meninggal $6,25 \pm 1,05$ dan pada kelompok yang tidak meninggal $3,78 \pm 1,38$ dan hasil tersebut berbeda secara bermakna. Hal ini didukung oleh penelitian sebelumnya, dimana didapatkan nilai rerata modified NUTRIC score pada kelompok yang meninggal adalah 6,16 dan pada kelompok yang tidak meninggal adalah 4,67 dan perbedaan rerata modified NUTRIC score tersebut berbeda bermakna antara kedua kelompok. ${ }^{10}$

Pada penelitian ini untuk skor APACHE II sebagai bagian dari modified NUTRIC score, didapatkan nilai rerata pada kelompok yang meninggal 26,83 $\pm 5,81$ dan pada kelompok yang tidak meninggal didapatkan nilai rerata sebesar $19,44 \pm 5,14$ dan dari hasil analisis menunjukkan perbedaan bermakna antara kelompok yang meninggal dan tidak meninggal. Hal ini sesuai dengan penelitian sebelumnya, didapatkan perbedaan yang bermakna dari skor APACHE II pada kelompok yang meninggal dan yang tidak meninggal, pada kelompok yang meninggal 30,3 dan pada kelompok yang tidak meninggal 23,9. ${ }^{10}$

Pada skor SOFA, yang merupakan bagian dari modified NUTRIC score, didapatkan nilai rerata pada kelompok yang meninggal 9,69 $\pm 2,37$ dan pada kelompok yang tidak meninggal didapatkan nilai rerata sebesar $5,71 \pm 2,17$ serta dari analisis didapatkan perbedaan bermakna antara kelompok yang meninggal dan tidak meninggal. Hal ini didukung oleh penelitian sebelumnya dimana skor SOFA pada kelompok yang meninggal adalah 11,1 dan pada kelompok yang tidak meninggal adalah 8, dan dari analisis perbedaan tersebut bermakna dengan nilai $\mathrm{p}<0,0001 .^{10}$

Modified NUTRIC score mempunyai kemampuan dalam memprediksi dengan benar kematian pasien sepsis sebesar 96\% dan benar memprediksi pasien sepsis hidup sebesar 71\%. Untuk nilai AUC didapatkan sebesar 0,916 artinya modified NUTRIC score dapat dijadikan sebagai marker untuk memprediksi kematian pada psien sepsis dengan kategori sangat baik.

Hasil penelitian ini menunjukkan adanya korelasiantara modified NUTRIC score berdasar atas cut-off point terhadap mortalitas pasien sepsis (nilai $p=0,000$ ). Hasil ini didukung oleh penelitian Jeong $\mathrm{dkk}^{8}$ yang membandingkan antara modified NUTRIC score dengan NUTRIC dalam memprediksi mortalitas dalam 28 hari pada 482 pasien dewasa dengan sepsis, dengan hasil nilai cut-off ROC curve dari modified NUTRIC score adalah 6 dengan sensitivitas $75,3 \%$ dan spesifisitas $64,8 \% .^{8}$ Dengan hasil tidak ada perbedaan yang bermakna antara kedua skor tersebut $(\mathrm{p}=0,45)$. Sehingga modified NUTRIC score merupakan alat skrining nutrisi yang baik untuk pasien sepsis. ${ }^{8}$ Pada penelitian sebelumnya didapatkan nilai cutoff terbaik adalah 5 dengan sensitivitas $72 \%$ dan spesifisitas 63\% dan AUC dari modified NUTRIC score terhadap kematian dalam 28 hari adalah $0,71 .^{8,9}$ Pada penelitian Vries dkk. ${ }^{5}$ juga menunjukkan kemampuan modified NUTRIC score dalam memprediksi mortalitas dalam 28 hari cukup baik (AUC 0,768; IK 95\%: 0,722-0,814) dan hasilnya lebih baik jika dibanding dengan MUST score yaitu skor yang umum digunakan untuk menilai nutrisi pada pasien di ruang perawatan biasa di Belanda. Penelitian lainnya juga menunjukkan ada korelasi yang sejalan dan kuat antara kecukupan nutrisi dengan mortalitas dalam 28 hari, dimana pasien dengan modified NUTRIC score tinggi memiliki tingkat mortalitas lebih tinggi dan berlaku sebaliknya. ${ }^{8,9}$

Penelitian yang dilakukan oleh Mendes dkk. $^{6}$ menunjukkan bahwa pasien kritis dengan modified NUTRIC score tinggi, didapatkan mortalitas dalam 28 hari lebih tinggi $(\mathrm{p}<0,001)$ (area under curve 0,658; IK 95\%: 0,620-0,696). ${ }^{6}$ Hal serupa juga didapatkan pada penelitian lain dengan hasil modified NUTRIC score yang tinggi $\geq 5$ memiliki tingkat kematian yang lebih besar yaitu $41,4 \%$ dibanding dengan $26,1 \%(\mathrm{p}<0,0)$ pada pasien dengan skor rendah. ${ }^{11}$ Menurut penelitian Moretti dkk. ${ }^{12}$ juga menunjukkan peningkatan 
angka mortalitas yang sebanding dengan tingginya modified NUTRIC score $(\mathrm{p}=0,000) .{ }^{12}$

Kelebihan dari penelitian ini adalah merupakan penelitian yang pertama kali dilakukan di Unit Perawatan Intensif RSUP dr.Mohammad Hoesin untuk menilai risiko nutrisi pada pasien sepsis. Kelemahannya adalah desain penelitian ini dilakukan retrospektif sehingga tidak bisa dilakukan intervensi terapi nutrisi.

\section{Simpulan}

Terdapat korelasi kuat antara modified NUTRIC score dengan mortalitas dalam 28 hari pada pasien sepsis yang di rawat di Unit Perawatan Intensif RSUP dr. Mohamamd Hoesin Palembang sehingga modified NUTRIC score yang tinggi dapat digunakan sebagai prediktor kuat kejadian kematian 28 hari pasien yang di rawat di ruang intensif. Lama perawatan, penyakit dasar, skor APACHE, dan skor SOFA juga merupakan faktor resiko penting terhadap kematian.

\section{Daftar Pustaka}

1. Singer M, Deutschman CS, Seymour CW, Shankar-Hari M, Annane D, Bauer M, et al. The third international consensus definitions for sepsis and septic shock (sepsis-3). JAMA J Am Med Assoc. 2016;315(8):801-10.

2. Lestari MI. Kegagalan resusitasi, kadar protein carbonyl dan kadar reseptorinteracting protein kinase 3 sebagai prediktor kematian pasien sepsis [disertasi]. Universitas Indonesia; 2019.

3. Wischmeyer PE. Nutrition therapy in sepsis. Crit Care Clin. In press 2017.

4. Lee ZY, Heyland DK. Determination of nutrition risk and status in critically ill patient: what are our considerations?. Nutrition in Clinical Practice. 2018;00 (0). American Society for Parenteral and Enteral Nutrition.

5. Vries MC, Koekkoek K, Opdam MH, Blokland D, Zanten A. Nutritional assesment of critically ill patient: validation of the modified NUTRIC score. European J Clin Nutr. 2018;72:428-35.

6. Mendes R, Policarpo S, Fortuna P, Alves M, Virella D, Heyland DK. Nutritional risk assessment and cultural validation of the modified NUTRIC score in critically ill patients-a multicenter prospective cohort study. J Crit Care. 2016;37:45-9.

7. Heighes PT, Doig GS, Simpson F. Timing and indication for enteral nutrition in the critically ill. Dalam: Seres DS, Van Way CW, penyunting. Nutrition support for the critically ill. Springer International Publishing Switzerland. 2016. hlm. 55-62.

8. Jeong DH, Hong SB, Lim CM, Koh Y, Seo J, Kim Y, dkk. Comparison of accuracy of NUTRIC and modified NUTRIC scores in predicting 28-day mortality in patients with sepsis: a single center retrospective study. Nutrients. 2018;10:911.

9. Rahman A, Hasan RM, Agarwala R, Martin C, Day AG, Heyland DK. Identifying critically-ill patients who will benefit most from nutritional therapy: further validation of the "modified NUTRIC" nutritional risk assessment tool. Clin Nutr. 2016;35(1):158-62.

10. Mukhopadhyay A, Jeyakumar H, Ong V, Leong CS, Teh AL, Van Dam RM, dkk. Association of modified NUTRIC score with 28-day mortality in critically ill patients. Clin Nutr. 2016;36(4):1143-8.

11. Kalaiselvan MS, Renuka MK, Arunkumar AS. Use of nutrition risk in critically ill (NUTRIC) score to assess nutritional risk in mechanically ventilated patients: a prospective observational study. Indian J Crit Care Med. 2017;21(5):253-6.

12. Moretti D, Bagilet DH, Buncuga $M$, Settecase CJ, Quaglino MB, Quintana R. Study of two variants of nutritional risk score "NUTRIC" in ventilated critical patients. Nutr Hosp. 2014;29(1):166-72.

13. Lew CCH, Cheung KP, Chong MFF, Chua AP, Fraser RJL, Miller M. Combining 2 commonly adopted nutrition instruments in the critical care setting is superior to administering either one alone. JPEN J Parenter Enteral Nutr. 2018;42(5):872-6. 
14. Prescott HC. The epidemiology of sepsis. Dalam: Wiersinga WJ, Seymour CW, penyunting. Handbook of sepsis. Switzerland: Springer; 2018.
15. Angele MK, Pratschke S, Hubbard WJ, Chaudry IH. Gender differences in sepsis: Cardiovascular and immunological aspects. Virulence. 2014;5(1):12-9 